$1-1-1930$

\title{
The West Virginia Community Packing House at Inwood as a State Service to Apple Growing
}

F.J. Schneiderhan

Follow this and additional works at: https://researchrepository.wvu.edu/ wv_agricultural_and_forestry_experiment_station_bulletins

\section{Digital Commons Citation}

Schneiderhan, F. J., "The West Virginia Community Packing House at Inwood as a State Service to Apple Growing" (1930). West Virginia Agricultural and Forestry Experiment Station Bulletins. 238.

https://researchrepository.wvu.edu/wv_agricultural_and_forestry_experiment_station_bulletins/239 @ WVU. It has been accepted for inclusion in West Virginia Agricultural and Forestry Experiment Station Bulletins by an authorized administrator of The Research Repository @WVU. For more information, please contact ian.harmon@mail.wvu.edu. 
West Virginia University Libraries

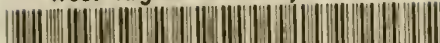

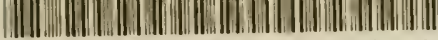

308021008961191 

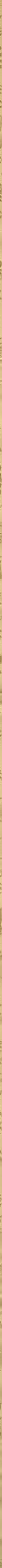


\section{West Virginia University Library}

This book is due on the date indicated

$$
\begin{aligned}
& \text { y }
\end{aligned}
$$

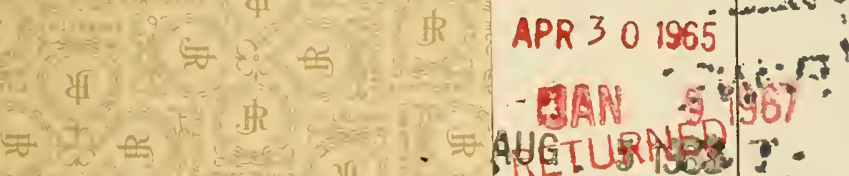

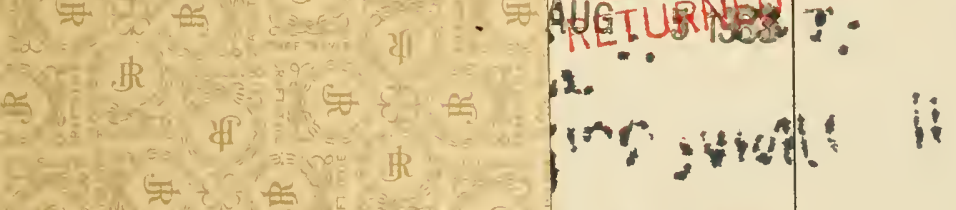

快

$5 s^{12}=$ 水

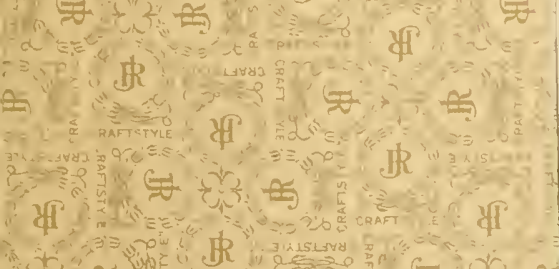

APR 301965 : 
Digitized by the Internet Archive in 2010 with funding from

Lyrasis Members and Sloan Foundation 


\title{
The West Virginia Community Packing House at Inwood as a State Service to Apple Growing
}

\author{
by F. J. SCHNEIDERHAN
}

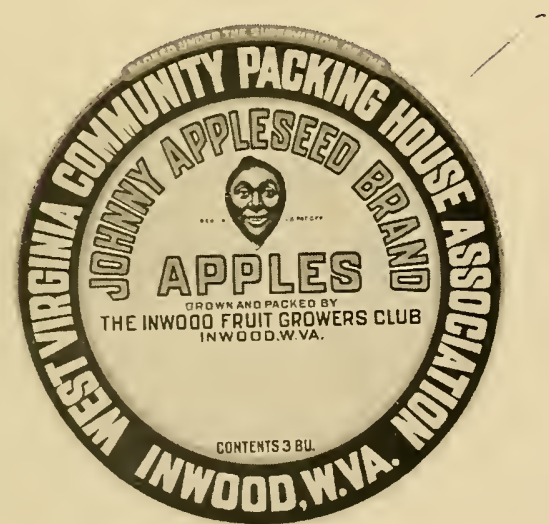

The Barrel Label for the U. S. No. I and Fancy Grades 


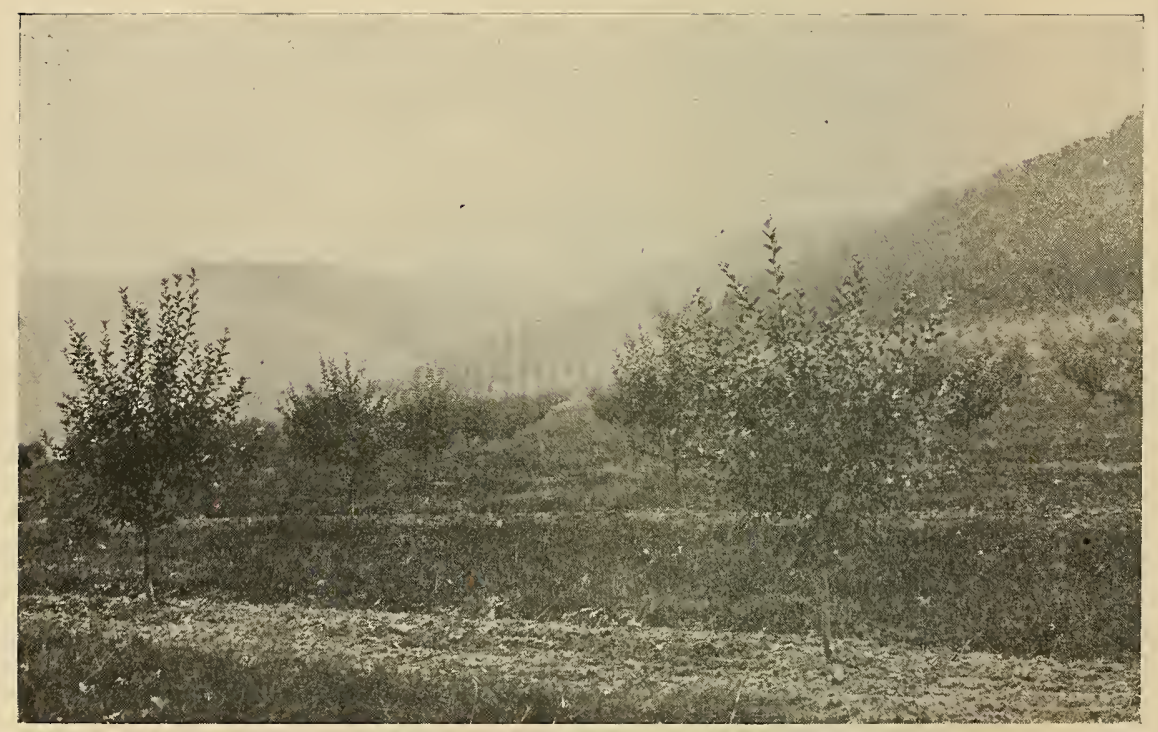

Typical terrain of orchard country in the Eastern Panhandle 


\section{The West Virginia Community Packing House at Inwood as a State Service to Apple Growing*}

by F. J. SCHNEIDERHAN

THE West Virginia Community Packing House at Inwood has been in existence since 1920 . During the 9-year period of its activities it has rendered important service to apple growing throughout the state and particularly in the Eastern Panhandle, where it is situated. The purpose of this bulletin is to present a report of a community cooperative packing plant originally and subsequently aided by state funds but actually functioning as a cooperative venture between the state and a group of apple growers designated as the Inwood Fruit Growers.

The history of the apple industry in the Eastern Panhandle is one of a multitude of production and marketing problems. As in other apple-growing sections, the chief problems in the early stages of the industry were those of production. Hundreds of varieties, including seedlings, were planted without regard to adaptation to the section. Little was known about the selection of orchard sites, planting distances, pruning, or fertilizing. Spraying was unknown. Whitewashing of treetrunks was considered the panacea for all the ills of apple trees. Artificial cold storage was unknown.

With the development of extensive apple-tree plantings came problems of pest control, the major ones being San Jose scale, codling moth, scab, and cedar rust. Investigations of the control of these pests were undertaken by the State Agricultural Experiment Station and the knowledge obtained was disseminated to the farmers.

The encroachment upon the market of carefully graded apples from the Pacific Northwest brought further hardship upon the eastern grower. The packing of inferior fruit brought the barrel pack into disrepute and opened the way for the introduction of the high-class boxed apples from the West. When a number of Panhandle orchardists undertook to pack a high grade of apples, they found their fruit in competition with poorer packs from the same district, and the price level was determined by such inferior grades.

*Submitted for publication March, 1929.

\section{Acknowledgment}

The author aclinowledges the assistance rendered by $H$. W. Prettyman, superintendent, and H. W. Hammersla, bookkeeper of the Inwood Packing House; J. J. Gardner and B. C. Boree of the U. S. Bureau of Agricultural Economics; and J. H. Brunk, superintendent of the C. H. Musselman Company by-products plant. 
The first efforts to meet this situation were directed toward selling the fruit rather than standardizing the grading and packing, but the history of these efforts is a series of failures. Among the few successful undertakings was the Martinsburg Fruit Exchange, strictly a sales agency organized along cooperative lines. This association became the logical group to lead the attempt to standardize the apple pack in the Panhandle.

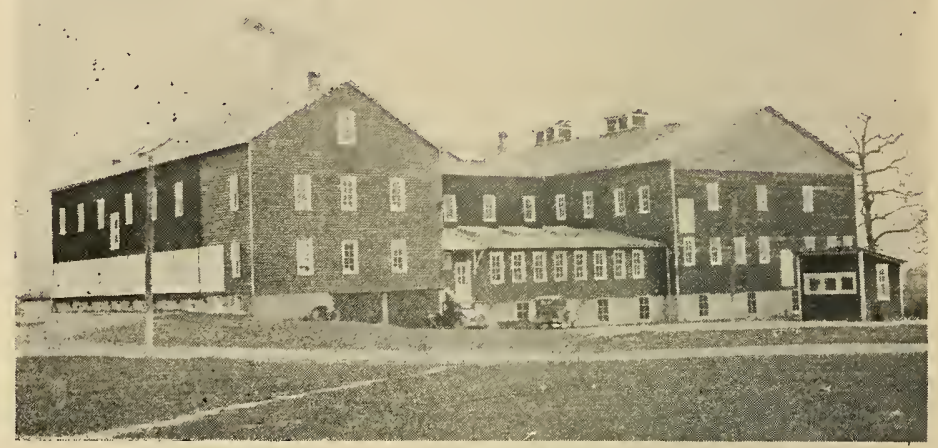

Fig. 1.-The West Virginia Community Packing House building, erected in 1920. The capacity of the packing house is approximately 40,000 barrels of apples per season. A total of 25,702,664 pounds of apples was handled in this building up to and including 1927

After a few years it was realized that the problem was larger than any single well-organized body could hope to counter successfully. The State Legislature was asked to assist. In 1919 an act was passed providing for the establishment of a demonstration packing plant. Objectives as stated in the act follow:

"Demonstration Community Packing House.-There is hereby established a demonstration community packing house to be located in the principal applegrowing section of the state, for the purpose of demonstrating the most approved methods of picking, sorting, and packing apples, peaches, and simllar fruit, and for the purpose of teaching any citizen of West Virginia approved methods of picking, sorting and packing said fruit in barrels, boxes, or other containers, and for the purpose of carrying the provisions and purposes of this act into effect a committee is hereby created consisting of the dean of the College of Agriculture of West Virginia University, the commissioner of agriculture, the president of the state Horticultural Society, the chairman of the horticultural committee of the state Farm Bureau Federation, and the horticulturist of the West Virginia Agricultural Experiment Station. It shall be the duty of the State Board of Control to procure a site, erect buildings and pre-cooling room, and provide the equipment and necessary space for the aforesaid demonstration. It shall be the duty of the State Board of Control when said building and school are provided and equipped as above stated to turn 1t over to the College of Agriculture of West Virginia University for operation and for carrying out of the purposes and intents herein set forth. Any appropriation hereafter made to carry out the provisions and purposes of this act shall be expended through the State Board of Control." 
Inwood was selected for the site as an important shipping point in the leading apple-producing county, and also because the growers there had shown a community spirit which commended itself to a committee designated in the act.

Plans for construction were formulated after a trip of inspection to the better apple-packing hunses of the East. The best features of these plants were incorporated in the plan of the building, together with certain new features, as for example the roller sorting belt which had not previously been used for apples, although in use in the citrus industry.

The packing plant was completed in 1920, and operations began in that year. A total of 120,000 bushels, the product of 12 orchards, was packed. All of this fruit was graded according to the "federal grades for barreled apples" and through special arrangements with the State Department of Agriculture and the United States Bureau of Agricultural Economics. All frutit sold was first inspected by licensed inspectors, thus originating in 1920 the shipping-point inspection service in the United States.

\section{The Eastery Paxhandle as an Apple-Growisg District}

The importance of the Eastern Panhandle in apple production, and the growth from 1910 to 1925, are shown in Table 1 by the numbers of apple trees in the six leading counties of the district.

TABLE 1.-Apple tree facts for the lcading onutics in the Eastern Panhandle district of Test Tirginia

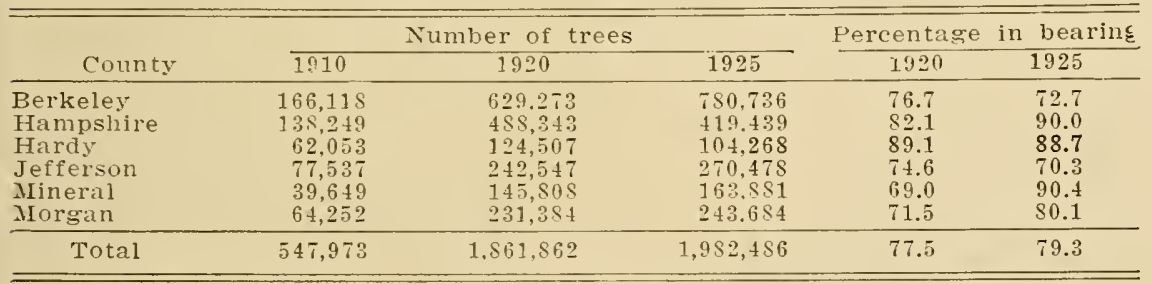

* Statistical Bulletins $S$ and 19 of the $[$. S. Department of Agriculture.

The very marked increase in number of apple trees for the decade from 1910 to 1920 will be noted. At the end of the decade there were approximately 3.4 times as many trees as at the beginning, and by 1925 the number had increased to approximately 3.6 times the number in 1910. While there has been only a slight increase in the number of apple trees for the district as a whole in the period from 1920 to 1925 , the rate of planting has been almost constant year for year, as shown by a comparison of the percentage of trees in bearing.

That the production of the district is essentially for out-of-state consumption is shown by the statistics of carload shipments from the leading shipping points (Table 2). These were obtained from the records of the Bureau of Agricultural Economics*. The shipments

*Data for years preceding 1926 are as published in Statistical Bulletins 8 and 19 of the L. S. Department of Agriculture 
are for calendar years, not for the apple-shipping seasons. Not all of the apples growin in a certain year are sold in that year; there is a carry-over to the early months of the next year. As a general rule, the last apples to be sold ont of cold storage are shipped to market late in April. The data for seasonal carload shipment records would be slightly different from those in Table 2 .

Martinsburg was the leading shipping point for the 8 -year period with 6009 carloads, and Inwood was second with 4771 carloads. (Fig. 2.) The importance of Romney as an apple-shipping point is manifest from the fact that it ranks third in the state in that respect.

TABLE 2.-Rank of the sixieen leading apple-shipping points of the Eastern Panhandle district, based on total carload shipments, 1920-27, inclusive

\begin{tabular}{|c|c|c|c|c|c|c|c|c|c|c|}
\hline \multirow[b]{2}{*}{ Station } & \multicolumn{10}{|c|}{ Number of carload shipments } \\
\hline & Rank & 1920 & 1921 & 1922 & 1923 & 1924 & 1925 & 1926 & 1927 & Total \\
\hline Martinsburg & 1 & 763 & 385 & 511 & 991 & 623 & 685 & 1041 & 1010 & 6009 \\
\hline Inwood & 2 & 546 & 75 & 424 & $\$ 92$ & 451 & 641 & 953 & 789 & 4771 \\
\hline Romney & 3 & 348 & 4 & 47 & 551 & 507 & 306 & 672 & 1084 & 3519 \\
\hline Charles Town & 4 & 359 & 242 & 67 & 619 & 362 & 338 & 830 & 522 & 3339 \\
\hline North Mountain & 5 & 390 & 25 & 156 & 539 & 164 & 203 & 460 & 472 & 2409 \\
\hline Paw Paw & 6 & 102 & 0 & 71 & 416 & 185 & 306 & 415 & 452 & 1947 \\
\hline Tabler & 7 & 325 & 36 & $18 S$ & 340 & 109 & 245 & 342 & 345 & 1930 \\
\hline Berkeley Springs & 8 & 134 & 104 & 0 & 360 & 125 & 54 & 487 & 262 & 1526 \\
\hline Kearneysville & 9 & 218 & 31 & 40 & 3.3 & 57 & 141 & 261 & 221 & 1312 \\
\hline Keyser & 10 & 157 & 9 & 46 & 195 & 82 & 70 & 124 & 239 & 916 \\
\hline Ridgeway & 11 & 144 & 14 & 36 & 103 & 60 & 145 & 223 & 143 & 868 \\
\hline Hancock & 12 & s & 25 & 58 & 188 & 43 & 53 & 228 & $13 \mathrm{~s}$ & 741 \\
\hline Shepherdstown & 13 & 85 & 29 & 28 & 156 & 27 & 50 & $17 \mathrm{~s}$ & 109 & 662 \\
\hline Snyder & 14 & 0 & 19 & 33 & 138 & 39 & 170 & 156 & 0 & 555 \\
\hline Shenandoah Jct. & 15 & 35 & 12 & 28 & 125 & 28 & 47 & 145 & 109 & 529 \\
\hline Rippon & 16 & 42 & 5.9 & 10 & 80 & 58 & 22 & 140 & 32 & 443 \\
\hline
\end{tabular}

Berkeley County is the leading apple-producing county in the state, just as Frederick County, bordering it, is in Virginia. However, there is no such preponderance of shipments from one point in West Virginia as there is from Winchester, Va. By far the largest number of carloads of apples grown in northern Virginia leave Winchester, while in the West Virginia section there are at least seven major shipping points.

The Packing Houge and its Relation to Apple Standardization and Grading in West Tirginia

In the early days of apple growing little care was given to proper grading until the superior pack of the western growers made better grading essential to successful competition. The packing plant was established to aid in the improvement of such apple grading. It is not alone responsible for the strides which have been made in apple standardization in West Virginia. The State Department of Agriculture, the Bureau of Agricultural Economics of the United States Department of Agriculture, and the West Virginia Horticultural Society have been important agencies in this development. The plant, however, made the original and most effective effort. The standardization of apple grades in West Virginia is therefore associated with it as the original nucleus. 
It was realized at the beginning of the fruit-grading work that trained inspectors were necessary, for standardization must be effected by careful inspection. A training school was established at the packing house in 1920. The schul has since been in session for about three weeks in every year except 1927. In 1928 abunt 40 inspectors were given training in the details of inspection, enabling them to inspect apples according to the requirements of the State

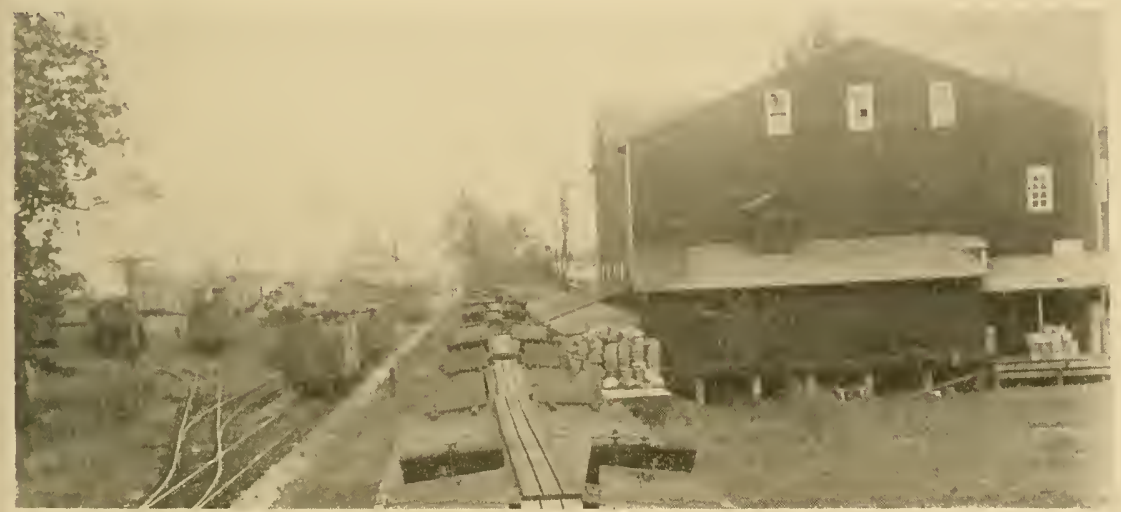

FIg. 2.-The rards at Inwood, W. Va., from which 4771 cars of apples were shipped during the S-year period 1920 to 1927 , inclusive. Inwood ranks second among the leading apple-shipping points in West Tirginia during this period. The Community Packing House is at the right

Department of Agriculture, in cooperation with the federal Bureau of Agricultural Economics.

Most of the students are residents of $W^{\top}$ est Virginia, but there have been some students from other states. Approximately 135 inspectors have been trained since this phase of the service started.

Study of the principles governing the marketing of apples and the general procedure necessary for successful inspection, lectures by a federal official concerning its practical phases, and actual inspection under observation. constitute the course of instruction. Upon successful completion of this course the student becomes an authorized federal inspector. He then is sent to some shipping point or packing plant to make inspections, and he may also instruct the growers in the requirements and methods of fruit grading. The efforts of the inspectors in teaching the growers proper grading methods are directed to eliminate the frequently occurring trouble of poor grading of apples.

The result of the training school for apple inspectors has been to create a reserve of trained men who are available for work in other states as well as in IVest Virginia. 
Fruit standardization as inaugurated at the Community Packing House has made rapid strides in West Virginia. The number of cars federally inspected in the Eastern Panhandle during the period 1922 to 1928 is as follows: in 1922,40 cars; 1923,109 cars; 1924,317 cars ; 1925, 1100 cars; 1926, 3000 cars; 1927, 2600 cars; and 1928, 2300 cars.

In spite of the marked increase in this work, the total number of cars inspected still represents only a small percentage of the total shipments of the whole section. The increase from 40 cars in 1922 to 3000 in 1926 indicates progress, and the prospects for further increase are very favorable. Approximately 60 percent of all the growers have part of their crop inspected,-evidence that the growers realize that the service pays.

\section{How Apples Are Handled Through the Community Packing House}

Let us assume that John Doe is a fruit grower near Inwood. In years past he has experienced considerable trouble, as others have, in getting reliable labor to pick and pack his apples. He decides to eliminate the element of chance from his grading tables by joining the Inwood Fruit Growers. His apple-growing business has thus been simplified and he can now concentrate on one main orchard operation-production. He signs a contract and agrees to deliver a definite part or all of his apples to the packing plant. He agrees further that his fruit is to be controlled by a joint committee consisting of representatives from the Growers and the Extension Division of the College of Agriculture-in this instance the superintendent of the packing house. This committee agrees to have fruit graded and inspected according to the state-federal regulations.

John Doe's fruit is handled through the plant and sold on the same basis as all other fruit brought in by the Inwood Fruit Growers. Before reaching the marketing stage let us see how the apples are handled at the packing plant. Six stages describe the progress through the plant:

(1) The apples are delivered in standard lug boxes by truck or other conveyance to the receiving platform. The driver gets a receipt showing the number of boxes of each variety delivered.

(2) The bookkeeper of the packing plant next determines the net weight of the fruit in the boxes and makes a record of it.

(3) The fruit is then placed on a conveyor and carried to polishing machines, after which it passes over an eliminator which removes all apples too small to be packed or canned. These small apples are known as "ciders". After the weight is recorded these apples are conveyed by belt to a large receiving bin, from where they are hauled by truck to the local vinegar factory or shipped by rail to other factories. 
(4) The renaining apples, the bulk of the lot, are now passed over a roller sorting belt where the sorters pick out the fruit unsuitable for packing. This fruit is designated "canners" and is conveyed by belt to boxes outside of the plant and hauled to the local canning plant or shipped to other by-products plants. No record of the weight of "canners" is made at this time, but after a given lot of apples has been graded and packed, the weight of canners is determined by subtracting the total weights of ciders and packed apples from the gross weight.

(5) The fruit has now been carefully sorted, and all defective apples showing insect or disease injuries and any other of the numerous injuries to which fruit is subject, have been removed. The apples are handled with particular care to prevent bruising and are finally packed in barrels or bushel baskets properly labeled according to grade and size. A record of the number of barrels or bushels of each grade and size run over the grader is kept for each variety of apples, and these packages are again converted into net weight of apples. The runner's record of a lot of Stayman is shown in Figure 3. This record is submitted to the bookkeeper.

(6) The grower's identity in connection with his packed apples is designated by a number stamped on the container, and not by his name. As the barrels or bushel baskets are loaded in the cars, a record of these numbers is made. Records are kept on the basis of pounds, and packages are identified by numbers, which simplify the records.

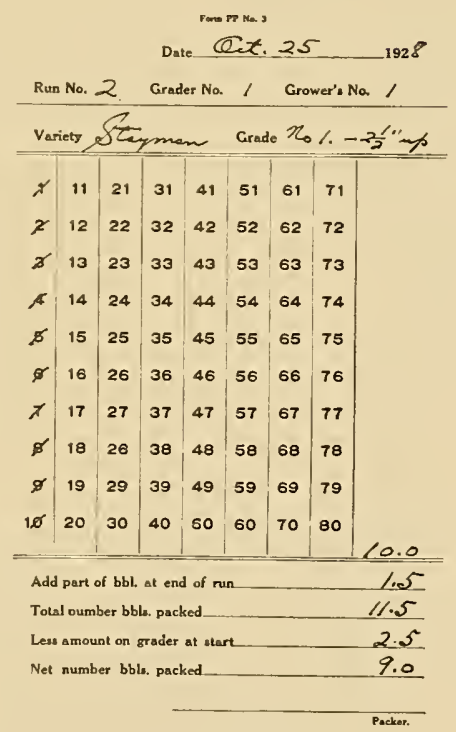

Fig. 3.-A rumer's record of a lot of Stayman apples that hare passed orer the grader. This record is prepared for every lot of apples belonging to different growers and is submitted by the rmmer to the booklieeper, who files it

\section{Selling the Fruit of the INwood Frutt Growers}

All of the fruit is sold by contract with a national terminal marketing agency. The contract is between the Inwood Fruit Growers and this selling agency. Representatives of the two organizations meet at the beginning of the marketing season to discuss probable marketing conditions, and a number of meetings are held throughout the picking season. Whenever a fruit grower is dissatisfied with prevailing prices he has the privilege of withdrawng his fruit from the general pool and placing it in cold storage to be sold after the normal 
marketing period of the apple pools. The sales period of apples belonging to the Inwood Fruit Growers is approximately ten weeks.

All apples are sold on the basis of variety pools throughout the season. The marketing agency returns to the grower an account sale which shows the price at which the fruit was sold, together with all deductions such as freight and handling charges.

The account sale is credited to the variety pool record, and 60 percent of the net proceeds is paid immediately to the fruit growers. The remaining 40 percent is retained to cover the packing costs and handling charges together with the cost of packages. When the final account sale is received for any variety or grade, the pool of this particular variety is closed, whereupon every grower receives credit for the total number of packages delivered to this pool and is paid at the average net price brought by the pool for the season. Full payment is made to all growers before December 1 .

In Table 3 is shown the 8-year record of sales for the eight leading varieties handled at Inwood. These returns represent the seasonal pool returns for all fruit and all grades for a certain variety after the selling charge has been deducted. The packing charge and cost of containers must still cone out of the returns.

TABLE 3.-Annual and average returns per barrel of the eight leading apple varieties handled in pools, by rank, 1920-1927, inclusive, at the Community Packing House

\begin{tabular}{|c|c|c|c|c|c|c|c|c|}
\hline Variety & 1920 & $1922^{\text {*k }}$ & 1923 & 1924 & 1925 & 1926 & \multicolumn{2}{|c|}{1927 Average } \\
\hline Stayman & $\$ 4.02$ & $\$ 2.9 \mathrm{~S}$ & $\$ 2.85$ & $\$ 4.12$ & $\$ 2.47$ & $\$ 2.26$ & $\$ 4.85$ & $\$ 3.36$ \\
\hline N. W. Greening & 2.89 & 3.15 & $1.8 \mathrm{~s}$ & 3.29 & 3.30 & 3.69 & 4.38 & 3.22 \\
\hline Black Twig & 3.02 & 2.74 & 2.82 & 3.36 & 2.68 & 1.72 & 5.40 & 3.10 \\
\hline Winesap & 3.63 & 2.18 & 2.48 & 3.20 & 2.33 & 2.83 & 5.04 & 3.09 \\
\hline Gano & 2.64 & 2.24 & 1.97 & 2.93 & 2.78 & 2.09 & 5.28 & 2.70 \\
\hline Grimes & 3.51 & & 1.84 & 2.46 & 1.86 & 1.36 & 4.09 & 2.52 \\
\hline York & 1.60 & 1.61 & 1.34 & 1.94 & 1.47 & 2.33 & 4.66 & 2.13 \\
\hline Ben Davis & .23 & 1.81 & 1.24 & 1.82 & 1.37 & 1.94 & 3.84 & 1.75 \\
\hline Average & 2.69 & 2.38 & 2.05 & 2.89 & 2.28 & 2.28 & 4.56 & \\
\hline
\end{tabular}

*No crop in 1921 because of freeze.

The returns in Table 3 probably will compare favorably with those of other selling agencies handling the same varieties over the same sales periods. The year 1927 shows by far the best returns. The average return for all the varieties considered in the table was $\$ 4.56$. The lowest average return occurred in 1923 , when only $\$ 2.05$ was realized. The average returns for 1923 were less than half those for 1927. The highest returns for the eight varieties were for Stayman. which brought an average of $\$ 3.36$ per barrel, while Ben Davis brought the lowest returns at $\$ 1.75$ per barrel. The highest return of all varieties in all of the years of the record was for Black Twig in 1927 , when $\$ 5.40$ per barrel was realized. The consistent high returns of Northwestern Greening give this variety high rank.

The Eastern Panhandle of West Virginia, and Frederick County, Virginia, are generally considered York Imperial sections because of the predominance of this variety. In sales at Inwood, however, this variety ranks next to the last. Its profitableness to the fruit grower no doubt lies more in its high yields than in its selling price. 
An expression formerly made by growers is, "Year in and year out. Ben Daris will make more nnoney than any other variety." The average returns of only $\$ 1.75$ per barrel for the 8 -year period would scem to contradict this statement. $1 \mathrm{t}$ is the opinion of economists who have studied the leading varieties in V'est Virginia and Virginia that the nembers of the Winesap family show a commanding lead over other varieties, a conclusion which is supported by the data in Table 3.

\section{Seilitig Applies bi Brind}

The use of brand names to identify apples in the state is growing every year. A few of the well-established brand names for West Virginia apples are "Blue Goose", "Johnny Appleseed", "Nountaineer", "Gold and Blue", "Cumberland Valley", "VTorth More", and "Peter Rabbit". The Inwood Fruit Growers" brand "Johnny Appleseed" has been packed since 1920. Two other brands, "Virginia Maid" and "Chef's Choice", were established in 1927. At present all apples packed at the Community Packing House are sold under one of these three brands. "Johnny Appleseed" meets the requirements of a U. S. No. 1 brand, and Fancy. The "Virginia Maid" brand corresponds to a U. S. No. 2, and "Chef's Choice" contains such apples as would be graded "unclassified". The labels of these brands are shown on the cover page and in Figures 4 and 5 .

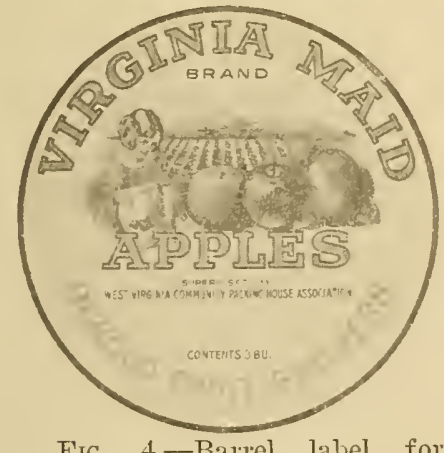

F'IG. 4.-Barrel label for "Virginia Maid" brand

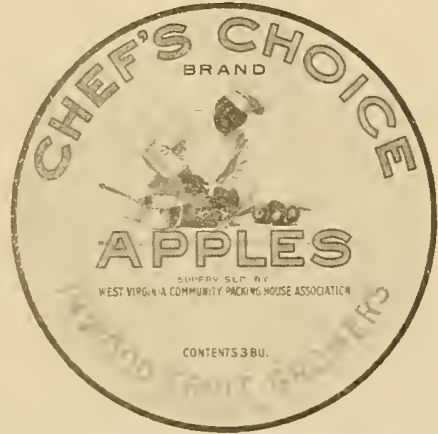

Fig. 5.-Barrel label for "Chef's Choice", brand

(Courtesy U. S. Department of Agriculture)

The Inwood Fruit Growers have packed more than 100,000 barrels of "Johnny Appleseed" since 1920: in 1920, 13.628 barrels; 1922, 8,576 bbls.; 1923, $20.9+1$ bbls.; $192 t$, 7.810 bbls. ; 1925, 13,106 bbls.; 1926, 26,467 bbls.; 1927, 6,032 bbls.; 1928, 20,6+0 bbls.; total, 117,200 bbls.

Of the "Virginia Maid" and "Chef's Choice" brands the following number of barrels were packed: in 1927, 2,000 bbls.; in 1928, 13,760 bbls.; total, 15,760 bbls. 
In addition to packing in barrels and baskets on a commercial scale, an increasing quantity of fruit has been packed in standard apple boxes and in special cardboard cartons for demonstrational use in direct-to-consumer marketing. Sufficient work has already been done to demonstrate the feasibility of marketing a considerable portion of the apple crop in this manner.

Observing the work of standardization, growers of other communities have begun to inquire how they, too, might benefit from the work done at the packing house. Under an arrangement with the Growers any group or individual grower desiring to use the "Johnny Appleseed" brand may do so, provided they meet the same conditions as required of the Growers. These conditions are embodied in a set of "Rules Governing the Extension and Use of the Johnny Appleseed Brand." As a matter of protection for the brand name a contract is drawn between the Association and the individual grower.

In 1923 three other groups were organized. These, together with the Inwood Fruit Growers, make up the West Virginia Community Packing House Association.

\section{Packing Costs at the Comalunity Packing Plant}

The grower who calculates costs of packing usually considers only labor and materials and, in some instances, light and power. He frequently fails to consider depreciation, interest on investment, and other items essential to correct and complete cost accounting. Furthermore, it is necessary to compare the costs of packing a certain grade of fruit at one packing plant with the same grade and quality packed at another. The quality of the tree run of apples is another necessary consideration.

To explain how the quality of the tree run affects the cost of packing let 11 s consider the case of Mr. A and Mr. B. The former grows a better quality of apples. Let us assume that the cost of handling a bushel of apples through the packing plant is 10c. Mr. A. raises apples of such quality that only four bushels are required to be run over the grader to pack a barrel of No. 1 apples. The cost of packing that barrel is $40 \mathrm{c}$.

Mr. B. grows a much inferior quality of apples. To pack one barrel of No. 1 apples, eight bushels of his tree run fruit are required at a cost of 80c. If $\mathrm{Mr}$. B. realizes the inferior nature of his apples, he may decide to pack two grades and in so doing he may get one barrel of No. 1 and one barrel of "unclassified" apples. He thereby reduces the cost per barrel to 40c. If he decides to pack only one barrel of No. 1 apples and sell the rest as canners he has still another problem, but his cost to pack that one barrel would remain at 80c.

It is evident that all of the factors involved must be considered in order to arrive at a basis for a true comparison of packing costs. Very few apple growers know exactly how much it costs to pack a barrel. If growers would keep such records, adequate comparisons and averages conld be drawn. 
Detailed records of the cost of packing both barrels and baskets have been kept by the Inwood Fruit Growers over a period of six years. Costs of packing a barrel of apples have averaged as follows: running. $4 \mathrm{c}$; sorting, $4 \mathrm{c}$; facing. $4 \mathrm{c}$; heading and nailing, $3 \mathrm{c}$; ringtailing, 1c; loading, 3c; coopering. 2c; labeling (lithographs) 1c; total, 22c.

In addition to these charges there are certain items of overhead expense such as replacement of machinery; interest, taxes, and insurance on supplies and for a sinking fund to cover the purchase of an additional tract of land; and other sundry items. All of these vary somewhat from year to year, but over a period of six years they have been found to amount to approximately 10 cents per barrel, in addition to the 22 cents itemized above, making a total packing cost of a barrel of apples at Inwood 32 cents. This cost is almost identical with that of two other well-managed packing houses in the section, at Martinsburg and in Frederick County, Virginia. All three have complete systems of bookkeeping, and records have been kept for a number of years. The average cost of packing at these three plants ivas $31.1 \mathrm{c}$.

Table 4 presents a one day's study of labor distribution. It serves to show the detail with which packing costs are calculated.

The number of growers who pack their fruit through the packing house has not changed materially from the beginning of operations. There has been a slight fluctuation in the total amount of apples packed because of the size of the crop. The capacity of the plant is approximately 40,000 barrels per season. In years of abnormally large crops a night shift is used. In such years many of the growers have hauled apples on a 20 -hour per day basis. It has been found, however, that night operation is uneconomical. The production of a 15-hour packing crew is lower proportionally than that of a 10 -hour crew. If the same crew works 15 hours, the efficiency after the 10hour period becomes appreciably less. When an unexperienced crew is used, the production is also below the standard of the regular 10hour day crew. Besides, the light bill exceeds the power bill for night operation.

\section{ApPle-Packing Records}

The packing records of the Community Packing House contain data on more than $25,000,000$ pounds of apples. In Tables 5 to 14 is given a detailed analysis of the packing record of the nine leading apple varieties grown in the Inwood section from 1920 to 1927 . A considerable range in the percentage of packed apples from year to year is noted. This range is due to seasonal and annual variation in weather which in turn is directly correlated with the severity of infestation by fungous diseases, insect pests, and other causes of injury.

Table 6, presenting a packing record of the Ben Davis apples handled at Inwood for the year 1920 to 1927, inclusive, shows that 
in 1927 the percentage of packed fruit was 70, while in 1925 the percentage was only 28.5. In 1924 the crop of Ben Davis was so severely russeted that the entire lot of 54,366 ponnds had to be sold as canners. The influence of seasonal conditions is well illustrated by this variety which is especially susceptible to weather and spray injury. The summary in Table it shows that the Ben Davis variety produced the highest percentage of culls and the smallest percentage of packed fruit. The average percentage of packed fruit for Ben Davis during the 8-year period under consideration was only 45.3 percent. The higest percentage in the nine varieties was 85.8 for Delicious.

TABLE 5.-Amounts of Tork Imperial apples received and amounts and percentages of pached and cull fruit, 1920-27, inclusive, at the Community Packing House

\begin{tabular}{|c|c|c|c|c|c|c|c|}
\hline rear & $\begin{array}{l}\text { Pounds } \\
\text { received }\end{array}$ & $\begin{array}{l}\text { Pounds } \\
\text { packed }\end{array}$ & $\begin{array}{c}\text { Percent } \\
\text { packed }\end{array}$ & $\begin{array}{l}\text { Pounds } \\
\text { canners }\end{array}$ & $\begin{array}{l}\text { Percent } \\
\text { canners }\end{array}$ & $\begin{array}{l}\text { Pounds } \\
\text { ciders }\end{array}$ & $\begin{array}{l}\text { Percent } \\
\text { ciders }\end{array}$ \\
\hline $\begin{array}{l}1920 \\
1921\end{array}$ & $1,664,471$ & $1,049,382$ & $\begin{array}{l}63.0 \\
\text { crop due }\end{array}$ & $\begin{array}{l}510,196 \\
\text { to freezing }\end{array}$ & 30.0 & 104,893 & 6.0 \\
\hline 1922 & $1,499,452$ & 848,445 & 57.0 & 486,302 & 33.0 & 164,705 & 10.0 \\
\hline 1923 & $1,820,925$ & 697,476 & 38.3 & S07, 492 & 44.3 & 315,957 & 17.3 \\
\hline 1924 & 195,730 & 104,434 & 53.4 & 74,441 & 38.0 & 16,855 & 8.6 \\
\hline 1925 & $1,320,371$ & 626,293 & 47.4 & 464,870 & 35.2 & $229,20 \mathrm{~s}$ & 17.4 \\
\hline 1926 & $2,157,525$ & $1,266,260$ & 59.0 & 852,407 & 39.0 & 38,858 & 2.0 \\
\hline 1927 & 662,521 & 343,970 & 51.9 & 247,781 & 37.3 & 70,770 & 10.8 \\
\hline Total & $9,320,995$ & $4,936,260$ & 53.6 & $3,443,489$ & 36.9 & 941,246 & 9.5 \\
\hline
\end{tabular}

TABLE 6.-Amounts of Ben Davis apples received and amounts and percentages of packed and cull fruit, 1920-27, inclusive, at the Community Packing House

\begin{tabular}{|c|c|c|c|c|c|c|c|}
\hline Year & $\begin{array}{l}\text { Pounds } \\
\text { received }\end{array}$ & $\begin{array}{l}\text { Pounds } \\
\text { packed }\end{array}$ & $\begin{array}{c}\text { Percent } \\
\text { packed }\end{array}$ & $\begin{array}{l}\text { Pounds } \\
\text { canners }\end{array}$ & $\begin{array}{l}\text { Percent } \\
\text { canners }\end{array}$ & $\begin{array}{c}\text { Pounds } \\
\text { ciders }\end{array}$ & $\begin{array}{l}\text { Percent } \\
\text { ciders }\end{array}$ \\
\hline $\begin{array}{l}1920 \\
1921\end{array}$ & 467,607 & 237,780 & $\begin{array}{l}50.0 \\
\text { crop due }\end{array}$ & $\begin{array}{l}207,710 \\
\text { to freezing }\end{array}$ & 44.0 & 22,117 & 5.0 \\
\hline 1922 & 185,519 & 116,652 & 63.0 & 60,167 & 32.0 & 8,700 & 4.0 \\
\hline 1923 & $2,187,560$ & 994,454 & 45.5 & $1,064,810$ & 48.7 & 128,296 & 5.8 \\
\hline 1924 & 54,366 & Bulked & None & 54,366 & 100.0 & None & \\
\hline 1925 & $1,353,640$ & 385,502 & 28.5 & 725,270 & 53.6 & 242,868 & 17.9 \\
\hline 1926 & $872,50 \mathrm{~s}$ & 435,667 & 50.0 & 243,415 & 28.0 & 193,426 & 22.0 \\
\hline 1927 & 611,501 & 89 & 70.1 & 166,441 & 27.2 & 15,971 & 2.7 \\
\hline Total & $5,732,701$ & $2,599,144$ & 45.3 & $2,522,179$ & 43.9 & 611,378 & 10.8 \\
\hline
\end{tabular}

The data in Table 14 point to one of the chief sources of loss in apple production in West Virginia and neighboring states. The percentage of apples unfit for packing is much too high for profitable apple-growing. The average percentage of packed apples for the nine leading varieties handled at Inwood during the 8-year period was only 58.5. Improving orchard spraying and cultural practices, to the end that the present packing percentage may be raised to approximately 85 to 90 percent, is a task to which every apple grower in the Eastern Panhandle might well dedicate his best efforts. Marked improvement may be effected by more thorough and timely spraying, together with better cultural practices.

It is common knowledge that in years of average production it is not difficult to sell high-grade apples. The real difficulty lies in the over-production of cull apples. There is little or no profit in raising 
TABLE 7.-Amounts of Grimes Golden apples received and amounts and percentages of packed and coll fruit, 1920-27, inclusive, at the Community Pucking Ilouse

\begin{tabular}{|c|c|c|c|c|c|c|c|}
\hline Year & $\begin{array}{l}\text { Pounds } \\
\text { received }\end{array}$ & $\begin{array}{l}\text { Pounds } \\
\text { packed }\end{array}$ & $\begin{array}{c}\text { Percent } \\
\text { packed }\end{array}$ & $\begin{array}{l}\text { Pounds } \\
\text { canners }\end{array}$ & $\begin{array}{l}\text { Percent } \\
\text { canners }\end{array}$ & $\begin{array}{l}\text { Pounds } \\
\text { ciders }\end{array}$ & $\begin{array}{l}\text { Percent } \\
\text { ciders }\end{array}$ \\
\hline $\begin{array}{l}1920 \\
1921 \\
1922\end{array}$ & 540,456 & $\begin{array}{r}366,608 \text { No } \\
\text { No }\end{array}$ & $\begin{array}{c}68.0 \\
\text { crop due } \\
\text { No }\end{array}$ & $\begin{array}{l}142,415 \\
\text { freezing }\end{array}$ & 26.0 & 31,433 & 5.0 \\
\hline 1923 & 614,655 & 430,325 & 70.0 & 101,587 & 16.5 & 82,743 & 13.5 \\
\hline 1924 & 248,325 & 188,788 & 76.1 & 35,813 & 14.4 & 23,724 & 9.5 \\
\hline 1925 & 496,607 & 256,425 & 51.6 & 188,001 & 37.8 & 52,181 & 10.6 \\
\hline 1926 & $1,116,280$ & 838,969 & 75.0 & 146,182 & 13.0 & 131,129 & 12.0 \\
\hline 1927 & 24,245 & 17,766 & 73.2 & 5,758 & 23.7 & 721 & 2.1 \\
\hline Total & $3,040,568$ & $2,098,881$ & 69.0 & 619,756 & 20.3 & 321,931 & 10.7 \\
\hline
\end{tabular}

TABLE S.-Amounts of N.W. Greening apples received and amounts and percentages of packed and cull fruit, 1920-27, inclusive, at the Community Packing House

\begin{tabular}{|c|c|c|c|c|c|c|c|}
\hline Year & $\begin{array}{l}\text { Pounds } \\
\text { received }\end{array}$ & $\begin{array}{l}\text { Pounds } \\
\text { packed }\end{array}$ & $\begin{array}{c}\text { Percent } \\
\text { packed }\end{array}$ & $\begin{array}{l}\text { Pounds } \\
\text { canners }\end{array}$ & $\begin{array}{l}\text { Hercent } \\
\text { canners }\end{array}$ & $\begin{array}{c}\text { Pounds } \\
\text { ciders }\end{array}$ & $\begin{array}{l}\text { Percent } \\
\text { ciders }\end{array}$ \\
\hline $\begin{array}{l}1920 \\
1921\end{array}$ & 319,452 & ${ }^{193,275}$ No & $\begin{array}{l}60.0 \\
\text { crop due }\end{array}$ & $\begin{array}{c}102,569 \\
\text { to freezing }\end{array}$ & 32.0 & 23,608 & 7.0 \\
\hline 1922 & 277,829 & 190,275 & 69.0 & 73,751 & 26.0 & 13,803 & 4.0 \\
\hline 1923 & 403,426 & 310,427 & 76.9 & 72,223 & 17.9 & 20,776 & 9.1 \\
\hline 1924 & 454,818 & 384,427 & 84.5 & 70,391 & 15.5 & & \\
\hline 1925 & 403,830 & 250,733 & 62.1 & 141,111 & 34.9 & 11,986 & 2.9 \\
\hline 1926 & 641,216 & 440,160 & 68.0 & 176,646 & 28.0 & 24,410 & 4.0 \\
\hline 1927 & 285,917 & 256,677 & 89.7 & 22,590 & 7.8 & 6,650 & 2.5 \\
\hline Total & $2,786,488$ & $2,025,974$ & 72.7 & 659,281 & 23.6 & 101,233 & 3.7 \\
\hline
\end{tabular}

TABLE 9.-Amounts of Stayman apples received and amounts and percentages of packed and cull fruit, 1920-27, inclusive, at the Community Packing House

\begin{tabular}{|c|c|c|c|c|c|c|c|}
\hline Year & $\begin{array}{l}\text { Pounds } \\
\text { received }\end{array}$ & $\begin{array}{l}\text { Pounds } \\
\text { packed }\end{array}$ & $\begin{array}{c}\text { Percent } \\
\text { packed }\end{array}$ & $\begin{array}{l}\text { Pounds } \\
\text { canners }\end{array}$ & $\begin{array}{l}\text { Percent } \\
\text { canners }\end{array}$ & $\begin{array}{l}\text { Pounds } \\
\text { ciders }\end{array}$ & $\begin{array}{c}\text { Percent } \\
\text { ciders }\end{array}$ \\
\hline $\begin{array}{l}1920 \\
1921\end{array}$ & 87,740 & ${ }_{\text {No }}^{60,831}$ & $\begin{array}{l}69.0 \\
\text { crop due }\end{array}$ & $\begin{array}{ll} & 25,036 \\
\text { to } & \text { freezing }\end{array}$ & 28.0 & 1,873 & 2.0 \\
\hline 1922 & 103,505 & 74,535 & 72.0 & 27,250 & 26.0 & 1,720 & 1.0 \\
\hline 1923 & 441,560 & 329,508 & 74.8 & 88,028 & 10.8 & 24,024 & 5.4 \\
\hline 1924 & 230,538 & 203,451 & 88.2 & 19,037 & 8.2 & 8,050 & 3.5 \\
\hline 1925 & 280,276 & 195,083 & 69.6 & 75,550 & 26.9 & 9,643 & 3.5 \\
\hline 1926 & 830,072 & 542,179 & 66.0 & 257,643 & 30.0 & 30,250 & 4.0 \\
\hline 1927 & 230,764 & 154,922 & 67.1 & 72,860 & 31.5 & 2,982 & 1.4 \\
\hline Total & $2,204,455$ & $1,560,509$ & 70.7 & 565,404 & 25.6 & 78,542 & 3.7 \\
\hline
\end{tabular}

TABLE 10.- Amounts of Blacl Twig apples received and amounts and percentages of packed and cull fruit, 1920-27, inclusive, at the Community Pacling House

\begin{tabular}{|c|c|c|c|c|c|c|c|}
\hline Year & $\begin{array}{l}\text { Pounds } \\
\text { received }\end{array}$ & $\begin{array}{l}\text { Pounds } \\
\text { packed }\end{array}$ & $\begin{array}{l}\text { Percent } \\
\text { packed }\end{array}$ & $\begin{array}{l}\text { Pounds } \\
\text { canners }\end{array}$ & $\begin{array}{l}\text { Percent } \\
\text { canners }\end{array}$ & $\begin{array}{c}\text { Pounds } \\
\text { ciders }\end{array}$ & $\begin{array}{l}\text { Percent } \\
\text { ciders }\end{array}$ \\
\hline $\begin{array}{l}1920 \\
1921\end{array}$ & $60,73 \mathrm{~S}$ & $\begin{array}{r}52,407 \\
\text { No }\end{array}$ & $\begin{array}{l}86.0 \\
\text { crop due }\end{array}$ & $\begin{array}{c}7,604 \\
\text { to freezing }\end{array}$ & 12.0 & 727 & 1.0 \\
\hline 1922 & 1,358 & 945 & 69.0 & 313 & 23.0 & 100 & 7.0 \\
\hline 1923 & 47,520 & 31,328 & 65.9 & 14,716 & 30.9 & 1,476 & 3.2 \\
\hline 1924 & 163,665 & 145,621 & 88.9 & 12,944 & 7.8 & 5,100 & 3.1 \\
\hline 1325 & 34,968 & 24,302 & 69.5 & 10,128 & 28.9 & 538 & 1.6 \\
\hline 1926 & 403,598 & 270,853 & 66.0 & 131,625 & 32.0 & 1,120 & 2.0 \\
\hline 1927 & 29,610 & 21,983 & 74.2 & 7,418 & 25.0 & 209 & .08 \\
\hline Total & 741,457 & 547,439 & 73.8 & 184,748 & 24.9 & 9,270 & 1.3 \\
\hline
\end{tabular}


TABLE 11.-Amounts of Hincsap apples rerivad and amounts and pereentages of paclicd and cull fruit, 1920-27, inclusive, at the Community Pacling Ifouse

\begin{tabular}{|c|c|c|c|c|c|c|c|}
\hline Ye: I & $\begin{array}{l}\text { Pounds } \\
\text { received }\end{array}$ & $\begin{array}{l}\text { Pommds } \\
\text { palcked }\end{array}$ & $\begin{array}{l}\text { Percent } \\
\text { packed }\end{array}$ & $\begin{array}{l}\text { Ponnds } \\
\text { canners }\end{array}$ & $\begin{array}{l}\text { Percent } \\
\text { canners }\end{array}$ & $\begin{array}{c}\text { Pounds } \\
\text { ciders }\end{array}$ & $\begin{array}{c}\text { Percent } \\
\text { ciders }\end{array}$ \\
\hline $\begin{array}{l}1920 \\
1521\end{array}$ & 27,774 & 21,381 & $\begin{array}{c}7 \% 0 \\
\text { crop due }\end{array}$ & $\begin{array}{c}5,(i 2 ! \\
\text { freezing }\end{array}$ & 20.0 & 761 & 2.0 \\
\hline 1922 & $19.75 \mathrm{~S}$ & 10,560 & 5.0 & 5,448 & 27.0 & 3,750 & 1.8 \\
\hline $19 \geq 3$ & 194,715 & 141,156 & 72.5 & 37,223 & 19.1 & 16,336 & 8.4 \\
\hline 1924 & $! 7,875$ & 75,660 & 77.3 & 15,115 & 15.4 & 7,100 & 7.3 \\
\hline 1925 & 154,928 & 64,263 & +1.5 & 34,003 & 21.9 & 56,662 & 36.6 \\
\hline 1927 & 144.786 & $90,0+3$ & $62.2^{\mathrm{N}}$ & 44,663 & 30.8 & $10,0 \mathrm{~S} 0$ & 6.9 \\
\hline Total & $639,8: 36$ & 403,066 & 62.9 & $142,0 \mathrm{~S} 1$ & 20.6 & 94,689 & 16.5 \\
\hline
\end{tabular}

TABLE 12.- Imounts of Gano apples received and amounts and percentages of pacted and cull fruit, 1920-27, inclusire, at the Community Pacting IIouse

\begin{tabular}{|c|c|c|c|c|c|c|c|}
\hline Year & $\begin{array}{l}\text { Pounds } \\
\text { receired }\end{array}$ & $\begin{array}{l}\text { Pounds } \\
\text { packed }\end{array}$ & $\begin{array}{l}\text { Percent } \\
\text { paclied }\end{array}$ & $\begin{array}{l}\text { Pounds } \\
\text { canners }\end{array}$ & $\begin{array}{l}\text { Percent } \\
\text { canners }\end{array}$ & $\begin{array}{c}\text { Pounds } \\
\text { ciders }\end{array}$ & $\begin{array}{c}\text { Percent } \\
\text { ciders }\end{array}$ \\
\hline $\begin{array}{l}1 \cong 20 \\
1921\end{array}$ & 51,103 & $\begin{array}{r}32,709 \\
\text { No }\end{array}$ & $\begin{array}{l}64.0 \\
\text { erop due }\end{array}$ & $\begin{array}{l}17,625 \\
\text { to }[\text { reezing }\end{array}$ & 34.0 & 769 & 1.0 \\
\hline 1922 & $46,33.3$ & 34,682 & 75.0 & 11,201 & 24.0 & 450 & 9.0 \\
\hline 1923 & 169,240 & 130,054 & 76.8 & 18.809 & 11.1 & 20,377 & 12.1 \\
\hline 1924 & 37,500 & 33,992 & 89.9 & $2,70 \mathrm{~s}$ & 7.3 & 1,100 & 2.8 \\
\hline 1925 & 94,054 & 83.726 & SS.9 & 6,218 & 6.6 & 4,110 & 4.4 \\
\hline 1926 & 116,794 & 62,155 & 53.0 & 34,639 & 29.0 & 20,000 & $1 \mathrm{~S} .0$ \\
\hline 1927 & 99,736 & 69,071 & 69.2 & $30,0>0$ & 30.2 & 595 & .06 \\
\hline Total & 615,060 & 446,389 & 72.5 & 121,270 & 19.7 & 47,401 & 7.8 \\
\hline
\end{tabular}

TABLE 13.-Amounts of Delicious upples reccived and amounts and percentages of pocked and cull fruit, 1920-27, inclusive, ot the Community Pacting Mouse

\begin{tabular}{|c|c|c|c|c|c|c|c|}
\hline Year & $\begin{array}{l}\text { Pounds } \\
\text { received }\end{array}$ & $\begin{array}{l}\text { Pounds } \\
\text { packed }\end{array}$ & $\begin{array}{l}\text { Percent } \\
\text { packed }\end{array}$ & $\begin{array}{l}\text { Pounds } \\
\text { canners }\end{array}$ & $\begin{array}{l}\text { Percent } \\
\text { canners }\end{array}$ & $\begin{array}{l}\text { Pounds } \\
\text { ciders }\end{array}$ & $\begin{array}{c}\text { Percent } \\
\text { ciders }\end{array}$ \\
\hline $\begin{array}{l}1920 \\
1921 \\
1922\end{array}$ & & & $\begin{array}{l}\text { No } \\
\text { No } \\
\text { No }\end{array}$ & & & & \\
\hline 1923 & 32.400 & 31,267 & 96.8 & 955 & 2.9 & 178 & 0.3 \\
\hline 1924 & 28,520 & 27,032 & 94.8 & 1,138 & 3.9 & 350 & 1.3 \\
\hline 1525 & 42,579 & 32,964 & 77.4 & 5,225 & 12.3 & 4,390 & 10.3 \\
\hline $19 \geq 6$ & 105,135 & $\$ 5,092$ & $\$ 1.0$ & 13,476 & 13.0 & 6,567 & 6.0 \\
\hline 1927 & 25,440 & 24,551 & 96.5 & $\$ 68$ & 3.0 & 21 & 0.5 \\
\hline Total & 234,074 & 200,906 & 85.8 & 21,662 & 9.6 & 11.506 & 4.6 \\
\hline
\end{tabular}

TABLE 14.-Summary showing amounts of each of the nine lending varieties of apples received at the Community House, together :ith amounts and percentages of packed and cull fruits, 1920-27, inclusive

\begin{tabular}{|c|c|c|c|c|c|c|c|}
\hline Variety & $\begin{array}{l}\text { Pounds } \\
\text { received }\end{array}$ & $\begin{array}{l}\text { Pounais } \\
\text { packed }\end{array}$ & $\begin{array}{l}\text { Percent } \\
\text { packed }\end{array}$ & $\begin{array}{l}\text { Pounds } \\
\text { canners }\end{array}$ & $\begin{array}{l}\text { Percent } \\
\text { canners }\end{array}$ & $\begin{array}{l}\text { Pounds } \\
\text { cidel's }\end{array}$ & $\begin{array}{l}\text { Percent } \\
\text { ciders }\end{array}$ \\
\hline York & $9,320,995$ & $4,936,260$ & 53.6 & $3,443, \pm 89$ & 36.9 & 941,246 & 9.5 \\
\hline $\begin{array}{l}\text { Davis } \\
\text { Grimes }\end{array}$ & $5,732.701$ & $2,599,144$ & 45.3 & $2,522,17 !$ & 43.9 & 611,378 & 10.8 \\
\hline $\begin{array}{l}\text { Golden } \\
\text { N. W. }\end{array}$ & $3,040,568$ & $2.098,881$ & 69.0 & 619,756 & 20.3 & 321.931 & 10.7 \\
\hline $\begin{array}{l}\text { Greening } \\
\text { Stay- }\end{array}$ & $2,7 S 6,4 S S$ & $2,025,974$ & 72.7 & 659,281 & 23.6 & 101,233 & 3.7 \\
\hline $\begin{array}{l}\text { man } \\
\text { Black }\end{array}$ & $2,204,455$ & $1.560,509$ & 70.7 & $565, \pm 04$ & 25.6 & 78,542 & 3.7 \\
\hline Twig & 741,457 & 547,439 & 73.8 & 1.94 .748 & 24.9 & 9,270 & 1.3 \\
\hline Winesap & $\quad 639,836$ & 403.066 & 62.9 & $1+2,0 \mathrm{~S} 1$ & 20.6 & 94,689 & 16.5 \\
\hline Gano & 615,060 & 446,389 & 72.5 & 121,270 & 19.7 & 47.401 & 7.8 \\
\hline Delicious & s 234,074 & 200,906 & 85.8 & 21,662 & 9.6 & 11,506 & 4.6 \\
\hline Total & $25,315,634$ & 14.818 .568 & 58.5 & $\$, 279,870$ & 22.7 & $2,217,196$ & 8.8 \\
\hline
\end{tabular}


these. When apple growers have learned to raise a high percentage of high-grade apples ( 85 to 90 percent of the tree crop), the marketing problem will be on the high road to solution and there will be greater profit in the enterprise. The great development of the apple by-products business in the Cumberland-Shenandoah region is striking proof of the failure of the grower to produce a high percentage of packable fruit.

A study of the packing records together with the sales returns makes possible an estimate of the dollar losses that result from producing apples under the average conditions prevalent in the Shenandoah apple region. The records of the Inwood Fruit Growers are believed to be representative not only of the rest of West Virginia, but also of the other states in the Cumberland-Shenandoah Valley apple section.

During the eight-year period a total of $25,702,664$ pounds of common varieties of apples were brought to the Inwood packing house. Only 58.5 percent were packed in containers and the remaining 41.5 percent were hauled to the by-products plants and sold as canners and ciders. Table 15 shows that 78 percent of the culls were canners and 22 percent, ciders.

TABLE 15.-Summary showing amounts of apples of all varieties received in each year of the 8-year period, 1920-27, together with the amounts and percentages of packed and cull fruit for each year and the total for the 8-year period at the Community Packing House

\begin{tabular}{|c|c|c|c|c|c|c|c|}
\hline Year & $\begin{array}{c}\text { Total } \\
\text { pounds } \\
\text { received }\end{array}$ & $\begin{array}{c}\text { Total } \\
\text { pounds } \\
\text { packed }\end{array}$ & $\begin{array}{l}\text { Percent } \\
\text { packed }\end{array}$ & $\begin{array}{l}\text { Total } \\
\text { pounds } \\
\text { canners }\end{array}$ & $\begin{array}{l}\text { Percent } \\
\text { canners }\end{array}$ & $\begin{array}{l}\text { Total } \\
\text { pounds } \\
\text { ciders }\end{array}$ & $\begin{array}{l}\text { Percent } \\
\text { ciders }\end{array}$ \\
\hline $\begin{array}{l}1920 \\
1921\end{array}$ & $3,259,151$ & $\begin{array}{r}2,044,346 \\
\text { No }\end{array}$ & $\begin{array}{l}62.7 \\
\text { crop due }\end{array}$ & $\begin{array}{l}1,027,970 \\
\text { to freezing }\end{array}$ & 31.5 & 186,835 & 5.7 \\
\hline 1922 & $2,149,477$ & $1,286,444$ & 59.8 & 668,955 & 30.6 & 194,078 & 9.6 \\
\hline 1923 & $6,033,934$ & $3,141,243$ & 52.3 & $2,232,731$ & 37.2 & 629,941 & 10.5 \\
\hline $1924 \%$ & $1,520,296$ & $1,171,624$ & $7 \overline{7.0}$ & 286,343 & 18.8 & 57,424 & 3.7 \\
\hline 1925 & $4,254,193$ & $1,965,971$ & 46.2 & $1,673,252$ & 39.4 & 614,970 & 14.4 \\
\hline 1926 & $6,280,712$ & $3,970,195$ & 63.2 & $1,863,024$ & 28.4 & 447,501 & 8.4 \\
\hline 1927 & $2,204,901$ & $1,467,897$ & 66.6 & 626,127 & 28.4 & 110,841 & 5.0 \\
\hline $\begin{array}{l}\text { Total } \\
1920- \\
1927\end{array}$ & $25,702,664$ & $15,047,720$ & 58.5 & $8,378,402$ & 32.5 & $2,241,590$ & 8.7 \\
\hline
\end{tabular}

Not all culls are preventable. There is a varying percentage of the tree crop that goes to the cull pile every year for causes beyond the control of the best orchard managers. Such causes as hail pecks, frost russet, sun scald, certain kinds of limb rubs, and fruit spots like York and King David spot, which are the result of an unbalanced physiological condition of the tree, are classed as non-preventable injuries. Such injuries, in addition to the small percentage of disease and insect injury which even the best kind of spraying fails to control, amount to approximately 12.5 percent. With these factors taken into account, a careful grower should pack about 87.5 percent of his total crop. In actual practice some growers in this section have packed more than 90 percent of their crop over a period of years. 
The diagram in Figure 6 represents the actual packing percentage and the percentage of culls indicated by the \&-year packing recurct of the Inwood packing hotse. Beside this diagram is another, showing the percentage of the tree crop that a careful grower should pack.

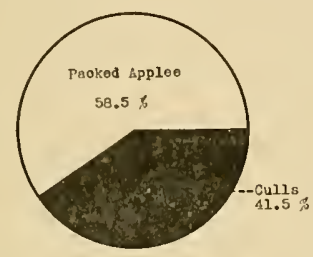

What the pooklns reoord 1a

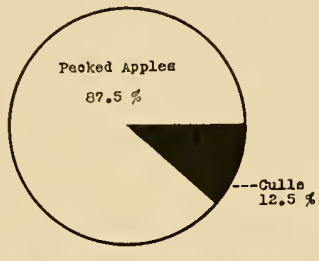

That the poolding reoord

ought to be

FIG. 6.-Diagrammatic representation of the alple-packing record for all varieties at the IVest Virginia Community Packing House during the 8-year period, 1920 to 1927 , inclusive

Analyzing the money loss resulting from packing 58.5 percent instead of 87.5 percent of the tree crop, we have the following:

\section{Sales Returns for the Lieading Varieties}

The average sales return for the eight leading varieties packed at Inwood during the 8 -year period, 1920 to 1927 inclusive, is $\$ 2.75$ per barrel. A total of approximately 173,668 barrels were hauled to the Inwood plant and of this amount only 58.5 percent were packed. The difference between this figure and 87.5 percent, the amount that should have been packed, is 29 percent, or 50.364 barrels. At $\$ 2.75$ per barrel the gross loss resulting from raising this quality of apples amounts to $\$ 138,500$. This is the amount of money that the culls should have returned.

However, 78 percent of these culls were sold as canners and 22 percent as ciders. The average price of canners during this period was approximately 75 cents per hundredweight and 42 cents per hundredweight for ciders. The canners therefore sold for $\$ 43,604$, and the ciders for $\$ 6,887$, or a total of $\$ 50,491$. Since the gross loss mentioned above is $\$ 138,500$ and the culls returned $\$ 50,491$, the net loss is $\$ 88,009$ for the eight-year period.

These figures serve to emphasize that a higher quality of apples, resulting from better orchard management, is essential to a more profitable business.

Records of the causes of cull apples in the Inwood section have been kept over a period of four years. Causes vary between wide limits from year to year. In some years hail and frost injury will cause most of the culls, while in other years diseases and insects will be more important. As a general rule, diseases are more important in 
years of heavy and continuous rainfall, while insects are more prevalent in dry, hot years.

Figure 7 represents the causes of cull apples at Inwood. The outstanding fact is that 29 percent of the total 41.5 percent of culls is due to preventable causes. Of these causes, fungous diseases and insect injuries do not produce as much loss as does the lack of good orchard cultural practices. The former cause 12.5 percent, while the latter accounts for 16.5 percent of the culls.

It is not surprising to find a larger percentage of culls caused by poor orchard practice, such as improper pruning, failure to thin, improper fertilization, and carelessness in handling, than from a lack of effective spraying, becalse spraying has been given especial attention in recent years through the spray service of the University.
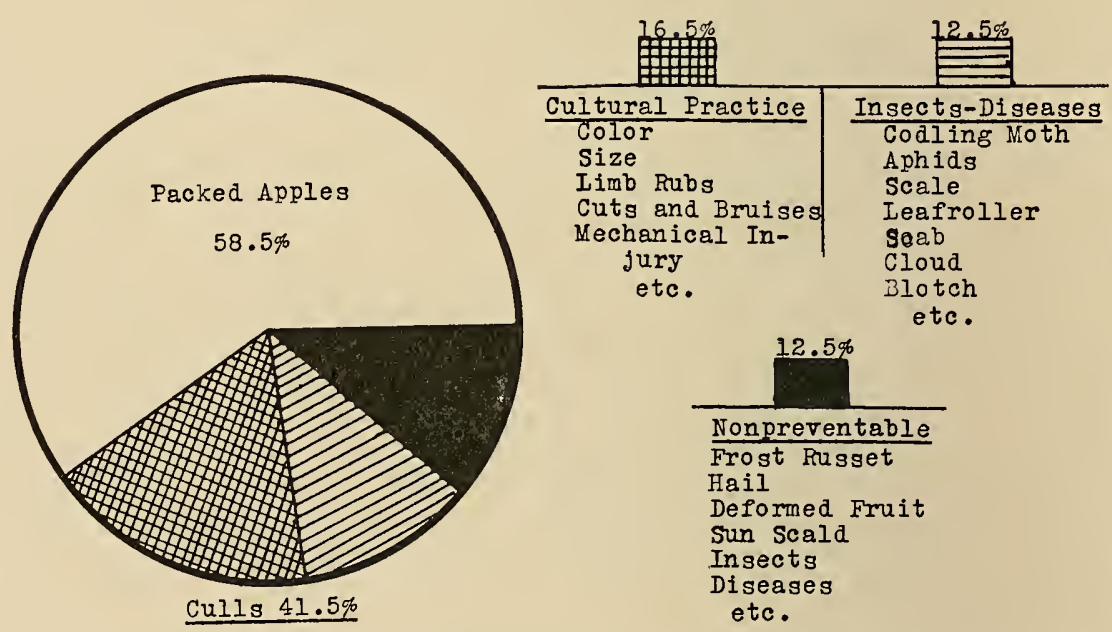

FIG. 7.-Diagrammatic representation of the apple-packing record for all varieties, together with an analysis of the cause of culls at the West Virginia Community Packing House for the 8-year period, 1920 to 1927, inclusive

Failure to produce a higher quality of apples has been due in part to the economic condition of the apple business within the past decade. Growers have been unable to invest money for spray equipment, materials, and labor for pruning and other orchard operations, because of several years of small profit and one of complete crop failure. In recent years the situation has been improving. During 1928 more spray rigs were sold than in the four previons years. Money for fertilizer and orchard operations is now becoming available. It is evident that with a return to favorable prices, greater attention will be given to production methods, and the quality of apples will doubtless be improved. 
'The Influexce of the Packing House

It has been generally recognized that in addition to leadership in apple standardization, the Community Packing House* is largely responsible for the adoption in West Virginia of modern grading machinery and the practice of packing in houses instead of on sorting tables in the orchard. Fifteen years ago grading machines were used in only a few of the better-managed orchards. Most of the packing was done in the orchard and the sorting was done over a table. Today we find only a few of these sorting tables in use and only in the smallest commercial orchards or in the poorly managed larger ones.

The advantages of the grading machine over the sorting table are manifest to anyone who has packed apples. Such machines remove the factor of human error in sizing the apples and have increased the daily output in barrels of packed fruit. The grading machine has been one of the important factors in expediting packing operations and incidentally preventing the losses resulting from heavy dropping and freezing in the latter part of the picking season. (Figure 8 shows a large grading machine in operation at the plant.)

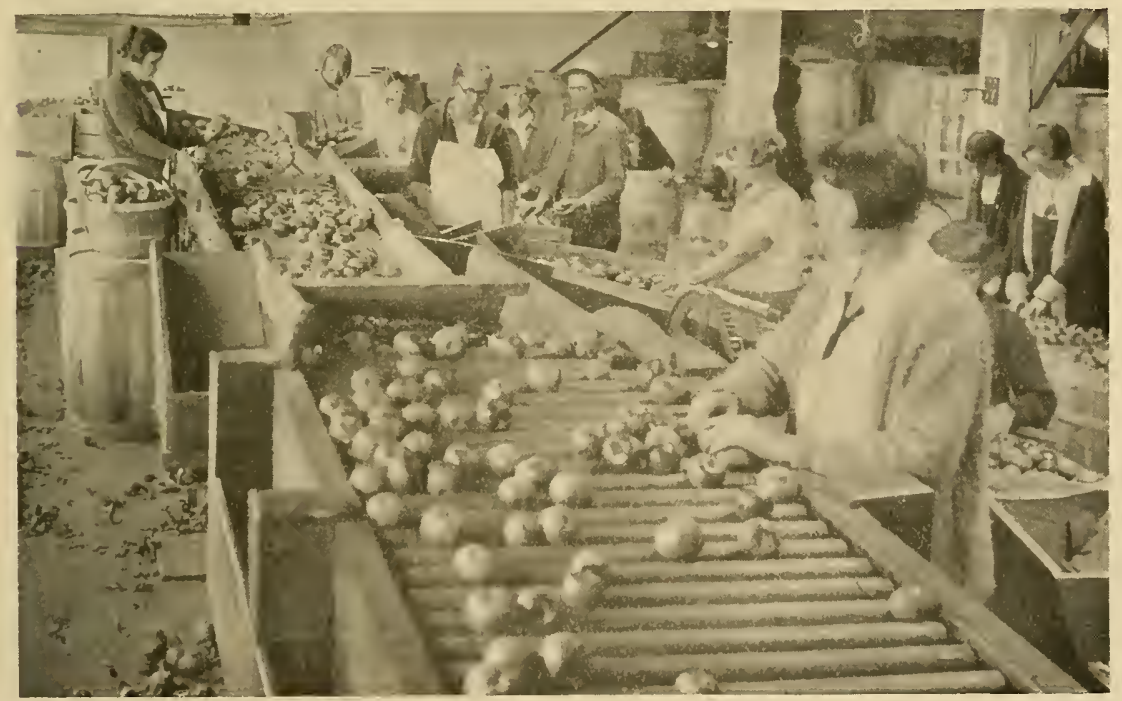

FIG. S.-A grading machine with a eapacity of 700 barrels a lay, used for demonstration and regular grading at the Community Packing House

(Courtesy $T$. S. Department of Agriculture)

*Inventory or real estate and equipunent as of June 30,1928 , includes the following: $4 \frac{1 / 2}{2}$ acres of land; the main bulldings and laboratoly of the packing unit; and the following equipment: Truscott grader, 2 Skinner rolling sorting belts, box elevator, Skinner barrel elevator, cull conveyor, belt roller conveyor, 5 Matthew gravity conveyors, 3 handy barrel presses, 8 electric motors, shafting and belts, auto truck scales, tools. saws, picks, shovels, etc., platform scales, time clock, wheel type roller conveyor, and maul sizing machine; besides the necessary office equipment. The total value of the plant is close to $\$ 45,000$. 
The influence of the packing plant in demonstrating different types of grading machines and in planning packing houses is an important accomplishment to its credit.

\section{APPENDIX}

THE C. H. MUSSELMAN COMPANY BY-PRODUCTS PLANT AT INWOOD*

The building, $500 \mathrm{ft}$. long, was erected in 1920 . Operations began in 1921. The building site covers eight acres and adjoins the right of way of the Cumberland Valley division of the Pennsylvania Railroad.

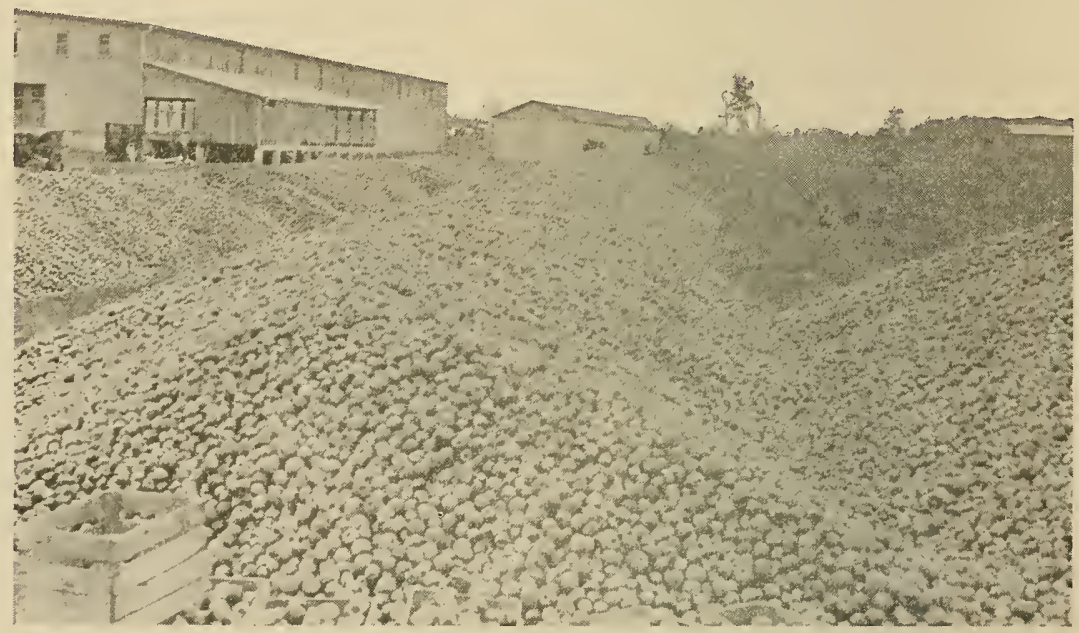

FIG. 9.-Two million pounds of apples stored on the ground prior to the canning operation. At the height of the picking season the capacity of the canning plant is insufficient to handle the supply of canners

The plant employs approximately 375 persons every crop year in a period of operation between September 1 and December 15. The labor comes from a radius of 15 miles around Inwood; about half the supply comes from within the town. A preponderance of female labor is used in this plant because the work requires quickness and dexterity. The company hauls its employees to work and for this purpose uses a number of busses. When busses cannot reach the homes of the workers, the company pays 25 cents for the trip from Martinsburg and immediate vicinity and 30 cents from the mountains 15 miles west of Inwood.

There are three main divisions of the female labor: 150 speckers, 40 peelers, and 22 slicers. All labor is employed on the piece-work

*This plant is described because it is part of the community development at Inwood. 
basis; the average wage earned is about $\$ 17.50$ per week. Some of the speckers who are paid six cents per bucket can turn out 100 huckets per day.

On some days as much as a half million pounds of cull apples is received. The daily capacity of the plant is about 300,000 pounds. When the incoming culls exceed the capacity of the plant, the apples are piled on the ground. A pile of two million pounds of such apples is shown in Figure 9. The average annual tonnage of cull apples handled since the opening of this plant has been about $22,500,000$ pounds, 一the equivalent of 8,333 carloads or 500,000 bushels. Approximately 273,800 cases of canned apples are produced annually together with 800,000 gallons of cider for the manufacture of vinegar.

This plant packs a solid pack of seed-celled apples and apple sauce in No. 10 tins, and apple-cider vinegar in barrels and assorted sizes of glass containers. The daily capacity of the plant is $25,000 \mathrm{No}$. 10 cans of solid-pack apples and sauce, 15,000 gallons of cider, and one carload of pomace which is shipped to pectin and jelly manufacturing plants.

Besides the vinegar and canning departments, this plant also packs apples in barrels and bushel baskets. The daily capacity of this department is approximately 340 barrels. A force of 30 persons is employed in this department.

\section{THE WEST VIRGINIA SPRAY SERVICE}

The Community Packing House has been the mainspring in the development of apple-grade standardization in West Virginia. The state, however, has gone further in its effort to aid the apple growers. Through various departments of the College of Agriculture and Agricultural Experiment Station it conducts research in insect and disease control. Through the West Virginia Spray Service, managed through the Extension Division, growers are advised when to spray and what materials to use.

In 1922, through the efforts of the extension pathologist, the first service of this kind in the state was given to the growers in the Eastern Panhandle. Letters advising when to begin and end a certain spray, and the amounts and kinds of materials to use, are sent to the growers.

The spray service had its inception in the control of scab, the most damaging apple disease in the few years just before 1922 . In that year 75 growers in Berkeley and Jefferson Counties received these spray service letters. So satisfactory was this arrangement that in 1923, 230 growers from 14 counties, the majority of them from the Panhandle, requested this feature. The nature of the spray service was explained by the county agents, through whose efforts, in cooperation with the extension pathologist, it expanded rapidly. 
In 1924 the service was extended to 370 growers in 31 counties involving a total of 900,000 bearing apple trees. In 1925 the list grew to 495 apple growers, covering: 36 counties and involving $1,000,000$ bearing trees. During 1926, 615 growers were served in 46 counties; in 1927 there were 775 growers in 47 counties, while in 1928,895 growers in 47 counties were served. Today the spray service affects approximately 2,000,000 bearing apple trees. The list of growers as it now stands includes practically every commercial apple grower in the state and a large number of smaller growers who raise fruit for local markets and home use. In 1925 the service was extened to include advice for spraying peaches.

\section{THE INWOOD DEVELOPMENT AS A COMMUNITY COOPERATIVE} EFFORT

Before the building of the packing house, Inwood consisted of a few houses and a railroad station noted as an important shipping point for apples. Since the opening of the plant the town has grown rapidly. Seven years ago a few straggling buildings surrounded the packing and by-products plants. Today there are a school, a new community church, and many substantial residences.

Packing plant and by-products plant here constitute a nearly complete and workable apple-handling unit. These plants have given employment to hundreds of persons from the surrounding community. They have been instrumental in retaining for the state large sums of money through the primary processing of a low-grade product which formerly was largely a waste product or else became diverted to points outside the state.

It is not alone in West Virginia that the packing plant is known. Numerous visitors and officials from other states and foreign countries come to the plant to study approved grading and packing equipment and methods of handling apples cooperatively.

Activities at Inwood have been limited chiefly to the applepacking season. Efforts are now being made to develop a betterrounded program. Cherry trees have been planted in large numbers and plans are being formulated to grow and can vegetables.

Through the cooperation of West Virginia University, its College of Agriculture, Experiment Station, and Extension Division, the State Department of Agriculture, and the Invood Fruit Growers, the Community Packing House has proved a helpful agency to the apple growers of West Virginia in disseminating information concerning methods of packing, branding, and marketing apples. 



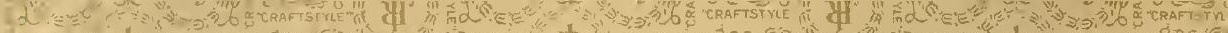

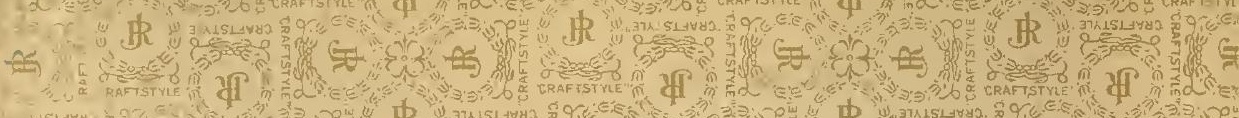

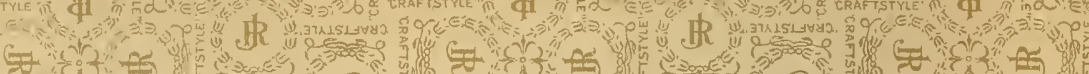
PI ( 央

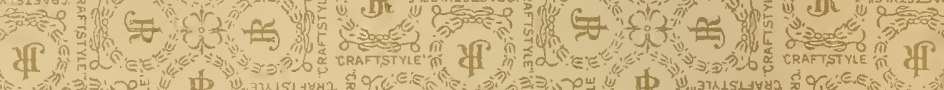

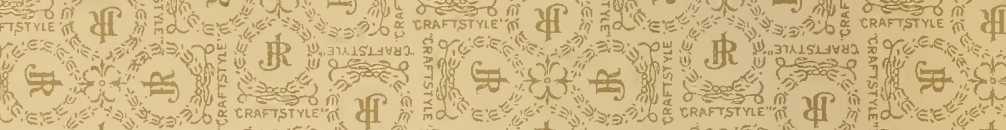

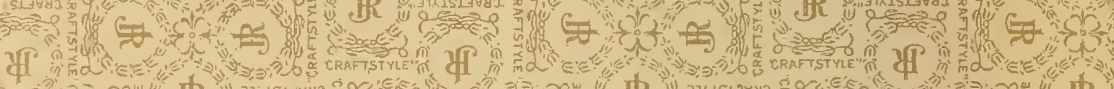

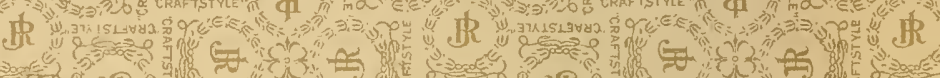

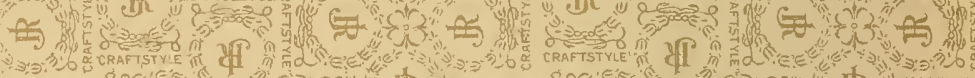

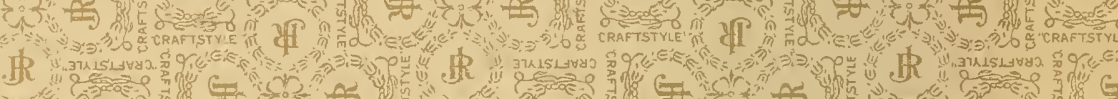

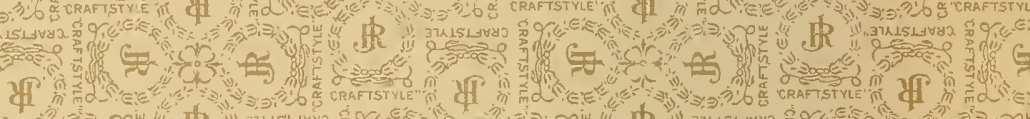

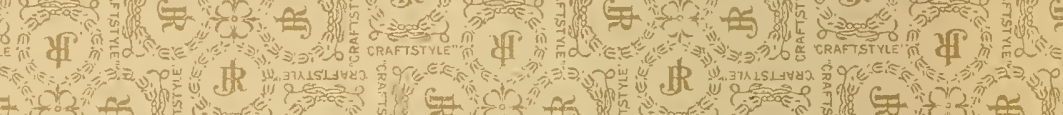

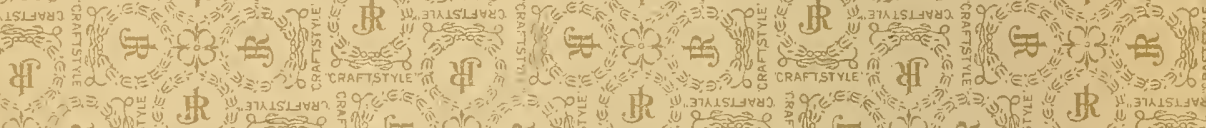
IR in

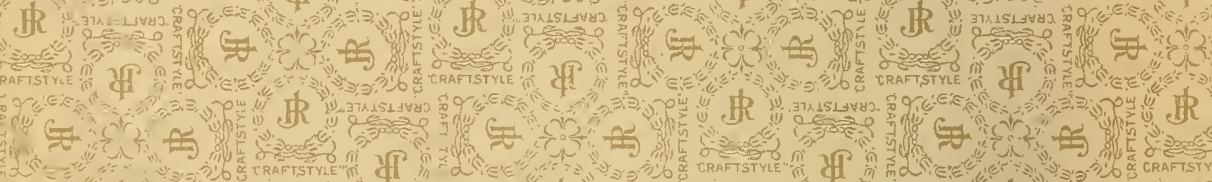

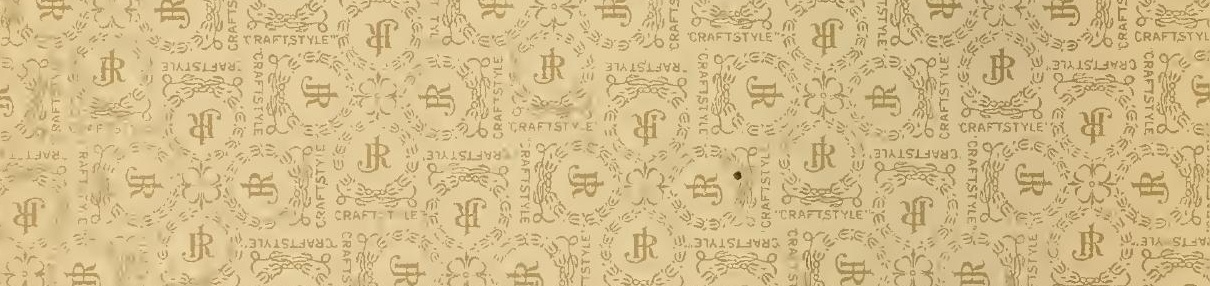

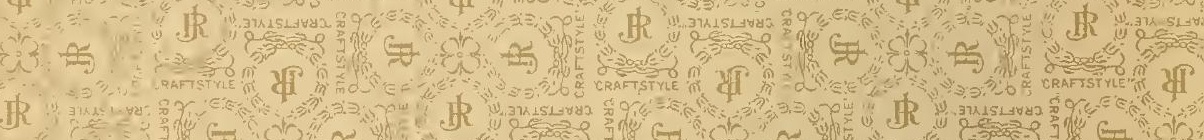

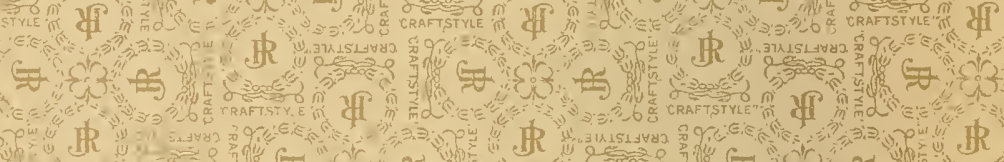

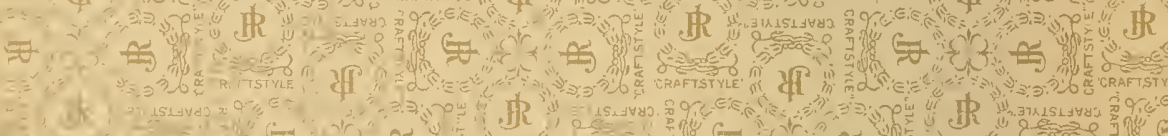

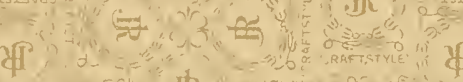
世
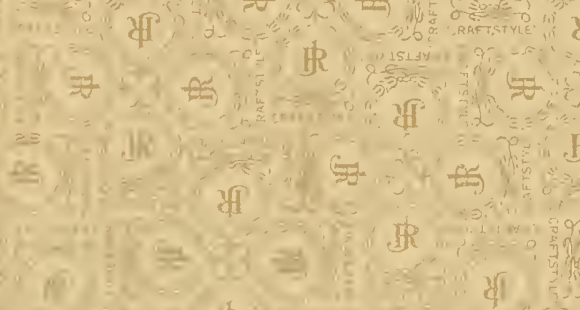

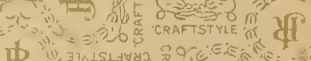

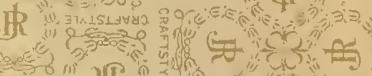
यI

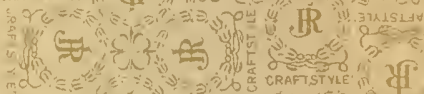

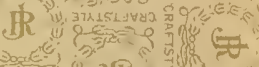

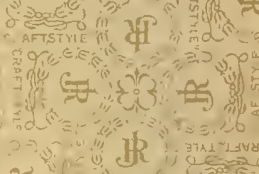
प्र 


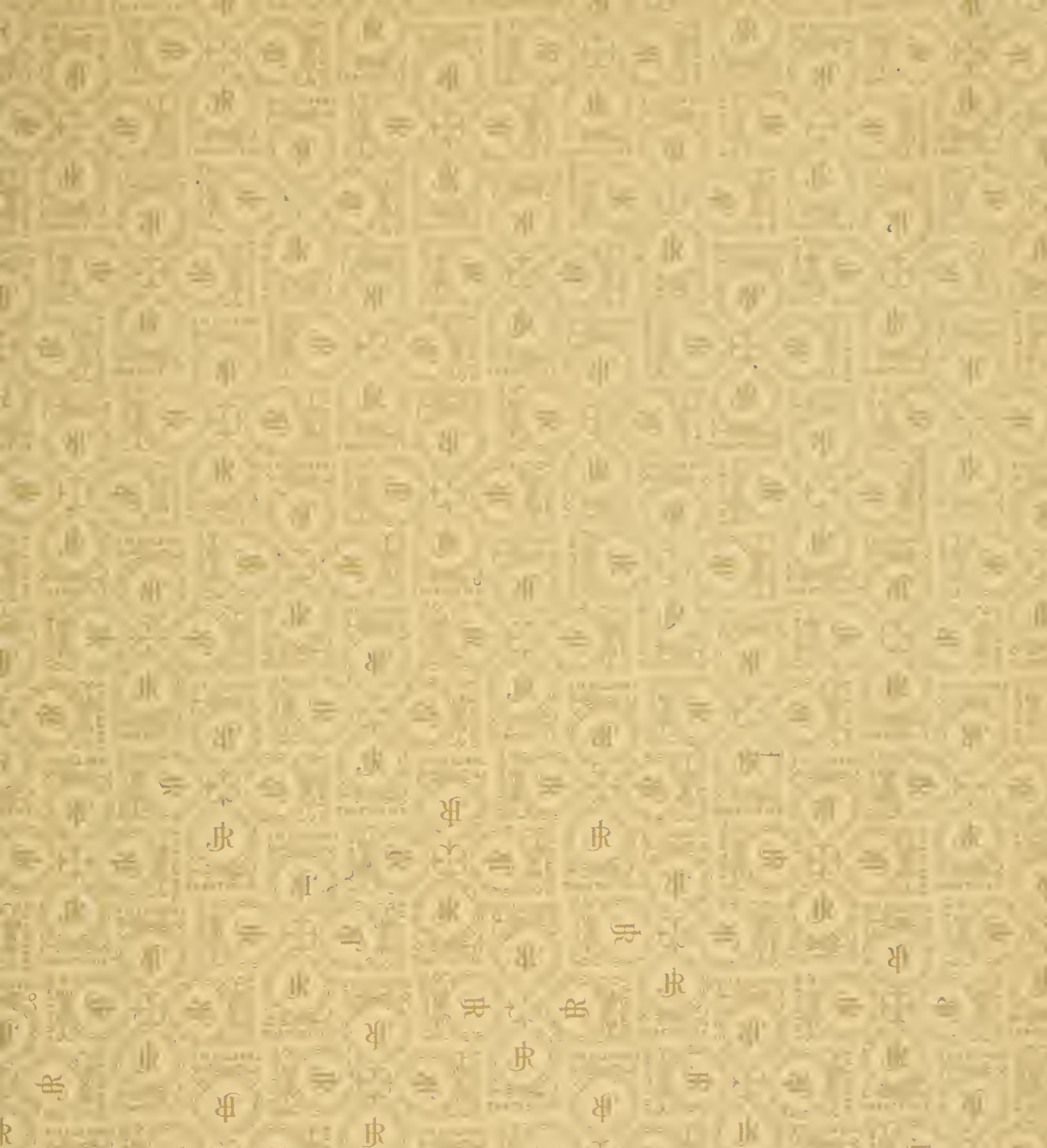

$\frac{1}{1}$

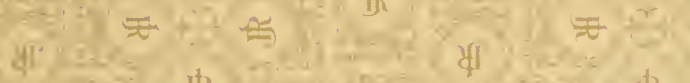

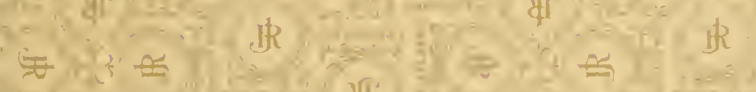

$\exists=\frac{1}{4}$

$\frac{1}{1}$

\section{$\div+\frac{\pi}{2}$}

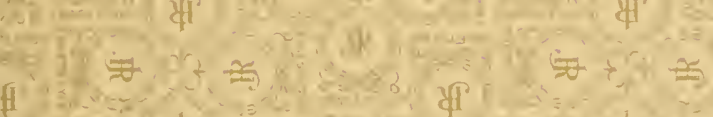

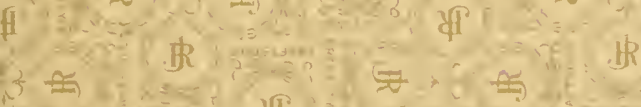

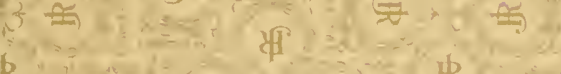

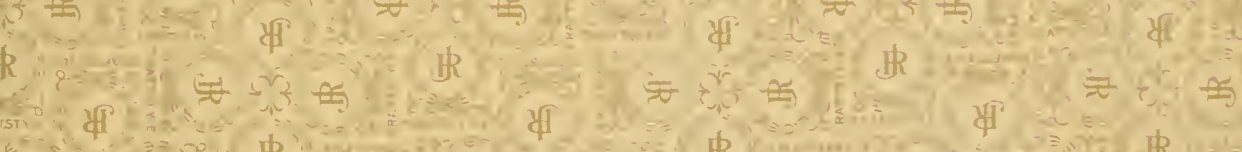

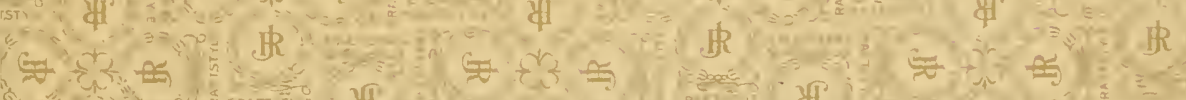

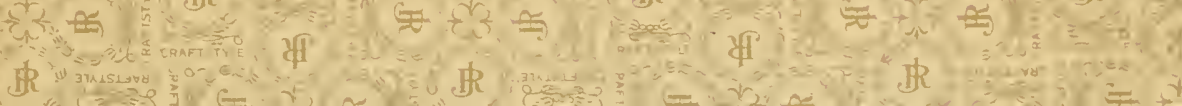


